\title{
ВИВЧЕННЯ АГЛІКОНІВ ФЛАВОНОЇДІВ СУХОГО ЕКСТРАКТУ ЛИСТЯ ШОВКОВИЦІ БІЛОЇ МЕТОДОМ ВИСОКОЕФЕКТИВНОЇ РІДИННОЇ ХРОМАТОГРАФІЇ
}

Вступ. Флавоноїди шовковиці білої представлені різними глікозидами, що ускладнює стандартизацію за їх вмістом як сировини, так і їі екстрактів. Зважаючи на різноманітність глікозидних фрорм фрлавоноїдів, присутність інших речовин френольної природи, які за аналітико-фрункціональними властивостями подібні до фрлавоноїдів, спектрофотометричне визначення останніх є утрудненим.

Мета дослідження - вивчити склад і вміст агліконів фрлавоноїдів у сухому екстракті листя шовковиці білої.

Методи дослідження. Сухий екстракт листя шовковиці білої отримували із сировини вітчизняного походження методом дробної мацерації; екстрагент - етанол (80-60%, об/об); екстракційне співвідношення сировина:екстрагент - 1:9-15, кратність екстрагування - 5, час одного екстрагування - 24 год. У дослідженні застосовували: роторний випарювач Laborota 4011 (Heidolph Instruments GmbH \& Co. KG, Німеччина), сушильну шафу CП-100 (UOSLAB, Україна), аналітичну вагу Mettler Toledo XP205DR (Mettler Toledo, Швейцарія), ультразвукову баню Bandelin Sanorex digitec (BANDELIN electronic GmbH \& Co. KG, Hiмеччина), рідинний хроматографр Agilent 1200 із детектором G1315D DAD Detector ("Agilent", CШA), хроматографрічну колонку Kromasil 100 C18 (0,125 м × 4,6 мм, 5 мкм, Supelko, СШA), стандарти агліконів (Sigma-Aldrich), хімічні реактиви аналітичної чистоти і розчинники для градієнтного елюювання (SigmaAldrich, Macron Fine Chemicals $\left.{ }^{\mathrm{TM}}\right)$.

Результати й обговорення. Аглікони фрлавоноїдів отримували шляхом кислотного гідролізу наважки сухого екстракту впродовж 2 год. Одержані аглікони вилучали шляхом вичерпної екстракції етилацетатом; відганяли розчинник, а сухий залишок, який містив досліджувані аглікони, розчиняли в метанолі, готуючи випробовувані розчини для ВЕРХ-вивчення. На хроматограмах випробовуваних розчинів спостерігали появу низки піків, три з яких відповідали мірицетину, кверцетину і кемпферолу. Отже, фрлавоноїди сухого екстракту листя шовковиці білої представлені глікозидами вказаних трьох фрлавонолів. Дані щодо наявності кверцетину і кемпферолу збігаються з даними досліджень інших авторів.

Висновки. Досліджено склад агліконів фрлавоноїдів сухого екстракту листя шовковиці білої. Встановлено, що вони представлені фрлавонолами: кверцетином, кемпферолом і мірицетином. Знайдено 0,20 \% кверцетину, 0,14\% кемпферолу і слідові кількості мірицетину - 0,003 \%. Отримані дані можна використати для розроблення методики стандартизації сухого екстракту листя шовковиці білої за показником "Кількісне визначення".

КЛЮЧОВІ СЛОВА: листя шовковиці білої; сухий екстракт; аглікони; кверцетин; кемпферол; мірицетин.

ВСТУП. Листя шовковиці білої є рослинною сировиною, яку застосовують у народній медицині багатьох країн як цукрознижувальний засіб при діабеті [1-3]. Ця лікарська рослинна сировина містить біологічно активні речовини (БАР), які поокремо або синергічно чинять гіпоглікемічну, гіполіпідемічну, гепатопротекторну, кардіоваскулярну, антиоксидантну, антитромботичну, протимікробну, противірусну, протипухлинну, протизапальну дію [4-11]. Дослідження складу й активності витягів/екстрактів із вітчизняних зразків цієі

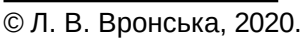

сировини вказують на можливість розробки на її основі нових лікарських засобів [11-16]. Хроматограсрічні дослідження фрлавоноїдів вітчизняних зразків листя шовковиці білої дозволили ідентифрікувати рутин, ізокверцитрин, кверцитрин і кемпорерол-3-O-ß-D-глюкозид [17]. Разом із тим, у хроматограсрічних профрілях метанольних витягів із сировини залишалися неідентифріковані сполуки. Вони мали характерну для фрлавоноїдів фрлуоресценцію зон на тонкошарових хроматограмах, а при дослідженні методом високоефективної рідинної хроматографрії (BEPX) неіденти- 
фріковані речовини мали спектри поглинання, притаманні фрлавоноїдам. Ці дослідження добре узгоджуються з даними вивчення складу фрлавоноїдів у польських, сербських, китайських, корейських, угорських зразках сировини [5, 8, 18-20], які в більшості випадків свідчать про присутність різних глікозидів кверцетину і кемпореролу в листі шовковиці білої. Лише поодинокі дослідження вказують на присутність глікозидів апігеніну і мірицетину $[5,9,21]$. Вказані відмінності можуть бути пов'язані з кліматичними особливостями регіонів зростання сировини та застосованими методами дослідження. Згідно з даними літератури, біологічна активність сировини та її екстрактів пов'язана з присутністю трьох основних фрлавоноїдів: рутину (кверцетин-3-О- $\beta$-рутино-

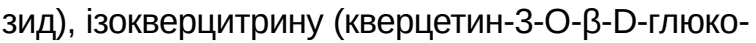

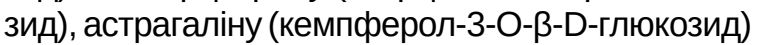
[5-10]. Тому фрлавоноїди - важливий клас БАР сировини листя шовковиці білої, саме вони $€$ активним маркером для ідентифікації і контролю якості сировини та її екстрактів. При кількісній стандартизації екстрактів важливі вибір умов і методів дослідження та визначення.

Мета дослідження - вивчити склад і вміст агліконів фрлавоноїдів у сухому екстракті листя шовковиці білої.

МЕТОДИ ДОСЛІДЖЕННЯ. СУхий екстракт листя шовковиці білої отримували із сировини вітчизняного походження методом дробної мацерації; екстрагент - етанол (80-60 \%, об/об); екстракційне співвідношення сировина:екстрагент - 1:9-15, кратність екстрагування - 5, час одного екстрагування - 24 год.

У дослідженні застосовували роторний випарювач Laborota 4011 (Heidolph Instruments $\mathrm{GmbH} \& \mathrm{Co}$. KG, Німеччина). Висушування екстрактів здійснювали при температурі 4550 С у сушильній шафрі СП-100 (UOSLAB, Україна) поличковим способом. Використовували аналітичну вагу Mettler Toledo XP205DR (Mettler Toledo, Швейцарія), а з метою підготовки проб для аналізу - ультразвукову баню Bandelin Sanorex digitec (BANDELIN electronic $\mathrm{GmbH}$ \& Сo. KG, Німеччина). Хроматографрвання здійснювали на рідинному хроматографрі Agilent 1200 із діодною матрицею G1315D DAD Detector ("Agilent", США), застосовували хроматографрічну колонку Kromasil 100 C18 (0,125 м × 4,6 мм, 5 мкм, Supelko, США).

У роботі використовували метанол, етанол, етилацетат, ацетон, гексаметилентетрамін, натрію сульфат, хлоридну кислоту аналітичної чистоти або чистоти, придатної для градієнтного елюювання у BEPX (Sigma-Aldrich, Macron Fine Chemicals ${ }^{\mathrm{TM}}$ ), стандартні зразки кверцетину, нарингеніну, кемпферолу, апігеніну, ізорамнетину, лютеоліну і мірицетину (Sigma-Aldrich).

Гідроліз глікозидів фрлавоноїдів сухого екстракту листя шовковиці білої виконували таким чином: до наважки екстракту додавали ацетон і розчин хлоридної кислоти та нагрівали на киплячій водяній бані впродовж 2 год. Аглікони фрлавоноїдів вичерпно екстрагували етилацетатом, а з отриманого витягу відганяли етилацетат у ротаційному випарювачі при температурі $40^{\circ} \mathrm{C}$. До одержаного сухого залишку додавали метанол, поміщали колбу в ультразвукову баню на 5 хв при температурі $25-30^{\circ} \mathrm{C}$, додавали розчин 250 г/л хлоридної кислоти, перемішували та хроматограсрували.

Розчини стандартів отримували, поміщаючи точну наважку відповідного стандартного зразка аглікону в мірну колбу місткістю 25 мл, додавали 20 мл метанолу і розчиняли, доводили об'єм розчину метанолом до позначки та перемішували. У мірну колбу відбирали необхідну кількість стандартного розчину, додавали розчин 250 г/л хлоридної кислоти, перемішували та хроматографрували.

Умови ВЕРХ-дослідження обрано шляхом модисрікації методики для гінкго листя [22], детально описано у [23].

РЕЗУЛЬТАТИ Й ОБГОВОРЕННЯ. РіЗНОМанітність глікозидних фрорм фрлавоноїдів, присутніх у листі шовковиці білої та її екстрактах, створює труднощі як з вибором стандартної речовини для перерахунку вмісту, так і з вибором, наприклад, аналітичної довжини хвилі при спектрофотометричому визначенні. 3 метою стандартизації умов вимірювання аналітичного сигналу, наприклад при спектрофотометричних вимірюваннях, усі глікозидні форми фрлавоноїдів переводять в аглікони [22]. Проте, при спектрофотометричних визначеннях в об'єктах із високим вмістом хлорофрілів, виникає ще одна проблема - хлорофіли мають близькі до фрлавоноїдів спектральні характеристики в електронних спектрах поглинання. Максимуми поглинання хлорофрілів перебувають у діапазоні довжин хвиль 430-460 та 600-660 нм, і їх молярні коефіцієнти поглинання є дуже високими [24, 25]. Вплив хлорофрілів на визначення фрлавоноїдів позначається завищенням значень вимірюваної оптичної густини. Застосування компенсаційних розчинів при вимірюванні не дає можливості повністю нівелювати цей вплив, якщо сировина/ екстракт характеризуються високим вмістом хлорофрілів, наприклад, коли сировиноює листя. Оптимальним методом аналізу таких об'єктів є BEPX, яка дозволяє одночасне розділення і визначення БАР. 
За вибраних хроматографічних умов, описаних у [23], аглікони фрлавоноїдів добре розділяються. Часи утримування речовин такі: мірицетин - 8,9 Хв, кверцетин - 14,7 ХВ, нарингенін 15,5 Хв, лютеолін - 16,6 хв, кемпферол-20,5 хв, апігенін - 21,4 хв, ізорамнетин - 21,8 хв. При хроматограсуванні випробовуваних розчинів сухих екстрактів листя шовковиці білої спостерігали піки трьох речовин-агліконів, які за часом утримування та ходом електронних спектрів поглинання ідентифрікуються як мірицетин, кверцетин і кемпферол (рис.). Піки трьох ідентифікованих агліконів добре розділені з піками інших БАР досліджуваного екстракту, що вказує на можливість їх подальшого BEPХ-визначення за вибраних умов. Для всіх зразків досліджуваних екстрактів площа піка кверцетину була найбільшою, дещо меншою - кемпферолу, площа піка мірицетину, порівняно з кверцетином і кемпоеролом, була дуже незначною. Апігеніну, про який говорили в публікаціях окремі автори, не виявлено, а мірицетин, як випливає 3 хроматограм, хоч і в незначній кількості, був присутнім серед агліконів фрлавоноїдів екстракту листя шовковиці білої [5, 9, 21].

При вивченні умов підготовки проб сухого екстракту листя шовковиці білої для BEPX-визначення агліконів фрлавоноїдів було досліджено умови гідролізу глікозидів фрлавоноїдів і вилучення агліконів, підібрано концентрації стандартних розчинів. Запропоновану методику приготування випробовуваних розчинів і розчинів порівняння наведено нижче.

Методика BEPX-визначення агліконів флавоноїдів у сухому екстракті листя шовковиці білої

\section{Випробовуваний розчин}

2,0 г (точна наважка) екстракту поміщали в конічну колбу місткістю 100 мл, додавали 1,0 мл 5 г/л розчину гексаметилентетраміну, 7,0 мл 250 г/л розчину хлоридної кислоти, 40,0 мл ацетону і кип'ятили 2 год із зворотним холодильником на киплячій водяній бані. Охолоджений розчин кількісно переносили в мірну колбу місткістю 50 мл, промиваючи конічну колбу ацетоном та доводячи об'єм розчину в мірній колбі до позначки, перемішували.

25,0 мл отриманого розчину переносили в ділильну лійку, додавали 25,0 мл води і тричі екстрагували етилацетатом порціями по 25, 15 та 15 мл упродовж 15 хв щоразу. Об'єднані етилацетатні витяги поміщали в ділильну лійку і двічі промивали водою порціями по 50 мл, струшуючи протягом 5 хв щоразу. Промитий водою етилацетатний витяг фрільтрували через паперовий фрільтр із 10,0 г натрію сульсрату безводного в колбу і відганяли етилацетат, застосовуючи роторний випарювач.

До отриманого сухого залишку додавали 8,0 мл метанолу, розчиняли із застосуванням ультразвукової бані впродовж 3 хв і кількісно переносили в мірну колбу місткістю 10 мл, додавали 1,6 мл розчину 250 г/л хлоридної кислоти, доводили об'єм розчину метанолом до позначки, перемішували.

\section{Вихідний стандартний розчин}

Точну наважку стандартних зразків мірицетину (5,0 мг), кверцетину (10,0 мг) і кемпсреролу (5,0 мг) поміщали в мірну колбу місткістю 25 мл, додавали 20,0 мл метанолу і розчиняли, доводили об'єм розчину метанолом до позначки, перемішували.

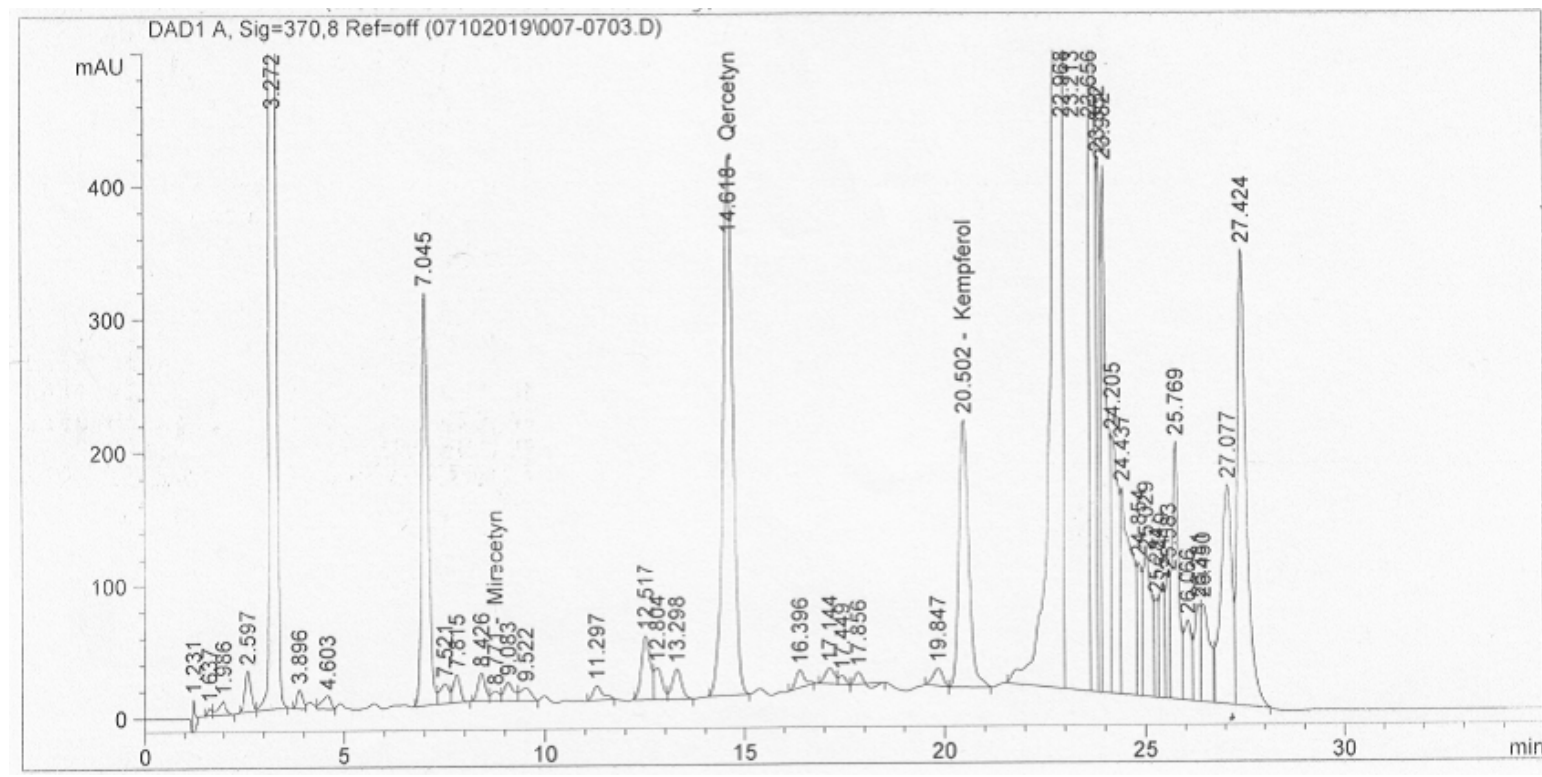

Рис. Типова хроматограма, отримувана для випробовуваних розчинів сухих екстрактів листя шовковиці білої за умов визначення агліконів фрлавоноїдів. 
Розчин порівняння 1

У мірну колбу місткістю 25 мл поміщали 0,5 мл вихідного стандартного розчину, додавали 2,0 мл розчину 250 г/л хлоридної кислоти, доводили об'єм розчину метанолом до позначки, перемішували.

Розчин порівняння 2

У мірну колбу місткістю 20 мл поміщали 10,0 мл вихідного стандартного розчину, додавали 1,6 мл розчину 250 г/л хлоридної кислоти, доводили об'єм розчину метанолом до позначки, перемішували.

Почергово хроматографрували по 10 мкл випробовуваних розчинів та розчинів порівняння 1 і 2, отримуючи не менше трьох хроматограм для кожного за умов, описаних вище. Послідовність піків на хроматограмах розчинів порівняння 1 і 2 - мірицетин, кверцетин, кемпфрерол.

Умови хроматографування. Хроматографрічна колонка: Kromasil 100 C18 розміром 0,125 м × 4,6 мм з розміром часток 5 мкм (Supelkо, США). Рухомі фрази: $\boldsymbol{A}-0,3$ г/л розчин фросфратної кислоти (рH 2,0), В - метанол. Програма елюювання: 0-1 хв: $60 \%$ фрази $\boldsymbol{A}$; 1-20 хв: $60 \rightarrow 45 \%$ фрази $A ; 20-21$ хв: $45 \rightarrow 0 \%$ фрази $A$; 21-25 хв: $0 \%$ фрази $A$; 25-27 хв: $0 \rightarrow 60 \%$ фрази $A$; 27-35 хв: 60 \% фрази А. Швидкість рухомої фрази: 1,0 мл/хв. Детектування: спектрофротометрично при довжині хвилі 370 нм. Інжекція: 10 мкл.

Вміст мірицетину (\%, у перерахунку на сухий екстракт) розраховували за фрормулою:

$$
X=\frac{2 \cdot m_{0} \cdot S_{x} \cdot 100 \cdot 100}{125 \cdot S_{0} \cdot m_{x}(100-W)},
$$

де $m_{0}$ - маса наважки стандартного зразка мірицетину, г;

$m_{x}$ - маса наважки зразка досліджуваного сухого екстракту, г;

$\mathrm{S}_{0}$ - середнє значення площі піка мірицетину, розраховане з трьох хроматограм розчину порівняння 1;

$S_{x}$ - середнє значення площі піка мірицетину, розраховане з трьох хроматограм випробовуваного розчину;

W - втрата в масі при висушуванні зразка досліджуваного сухого екстракту, \%.

Вміст кверцетину/кемпореролу (\%, у перерахунку на сухий екстракт) розраховували за фрормулою:

$$
X=\frac{m_{0} \cdot S_{x} \cdot 100 \cdot 100}{2,5 \cdot S_{0} \cdot m_{X}(100-W)},
$$

де $m_{0}$ - маса наважки стандартного зразка відповідного аглікону, г;

$m_{x}$ - маса наважки зразка досліджуваного сухого екстракту, г;

$S_{o}$ - середнє значення площі піка відповідного аглікону, розраховане з трьох хроматограм розчину порівняння 2;

$S_{x}$ - середнє значення площі піка відповідного аглікону, розраховане з трьох хроматограм випробовуваного розчину;

W - втрата в масі при висушуванні зразка досліджуваного сухого екстракту, \%.

Результати визначення вмісту мірицетину, кверцетину і кемпферолу в сухому екстракті листя шовковиці білої наведено в таблиці.

Таким чином, результати ВЕРХ-дослідження і кількісного визначення трьох зразків екстракту листя шовковиці білої вказують на те, що фрлавоноїди представлені, головним чином, глікозидами кверцетину і кемпореролу та містять глікозиди мірицетину. Після кислотного гідролізу впродовж 2 год знайдено агліконів: 0,20\% кверцетину, 0,14\% кемпферолу і слідові кількості мірицетину - 0,003 \%. Ці дані узгоджуються 3 результатами досліджень інших авторів щодо домінування глікозидів кверцетину і присутності глікозидів кемпоеролу в сировині та екстрактах листя шовковиці білої [5-10, 18-20].

У роботі [5] опубліковано дані відносно вмісту фолавоноїдів у десяти зразках сировини листя шовковиці білої власного збору (різні регіони Республіки Корея) і трьох аптечних зразках. Для отримання досліджуваного вилучення застосовано $90 \%$ етанол, співвідношення сировина:екстрагент становило 1:20, екстрагування тривало 4 год за температури $60{ }^{\circ} \mathrm{C}$. У результаті було визначено середній вміст рутину $(0,310$ та $0,175 \%)$, ізокверцитрину (0,568 і 0,564 \%), астрагаліну (0,241 та 0,356 \%), відповідно, для дикорослих і аптечних зразків сировини листя шовковиці білої [5]. Ці дані підтверджують домінування глікозидів кверцетину - рутину й ізокверцитрину, значним є вміст глікозиду кемпферолу - астрагаліну. Польські дослідники за допомогою гарячої води (80-90 $\left.{ }^{\circ} \mathrm{C}\right)$ одержали екстракти при співвідношенні сировина:екстрагент 1:10, нагрівання здійснювали впродовж 5 хв.

Таблиця - Вміст флавоноїдів у сухому екстракті листя шовковиці білої

\begin{tabular}{|c|c|c|c|c|}
\hline \multirow{2}{*}{ Серія екстракту } & \multicolumn{4}{|c|}{ Вміст, у перерахунку на суху речовину, \% } \\
\cline { 2 - 5 } & мірицетин & кверцетин & кемпорерол & разом \\
\hline 01 & 0,004 & 0,205 & 0,144 & 0,353 \\
\hline 02 & 0,003 & 0,216 & 0,157 & 0,376 \\
\hline 03 & 0,002 & 0,190 & 0,129 & 0,321 \\
\hline
\end{tabular}


В отриманих екстрактах знайдено: рутину $0,91 \%$, ізокверцитрину - 0,54 \% і астрагаліну 0,32 \% [18]. Сербські вчені дослідили склад екстрактів, одержаних з листя шовковиці білої [19]. Як екстрагент було використано 70 \% етанол, співвідношення сировина:екстрагент - 1:15, екстрагування здійснювали трикратно за температури $30^{\circ} \mathrm{C}$ впродовж 24 год щоразу свіжими порціями екстрагенту [19]. ВЕРX-аналіз отриманого екстракту вказав на присутність рутину 0,289 \% [19], відсутність вільного кверцетину, а інших глікозидів і агліконів у роботі [19] не визначали. Результати дослідження фрлавоноїдів у плодах шовковиці білої різного ступеня зрілості описано у [23]. Пакистанські вчені встановили, що при достиганні плодів знижується вміст глікозидів кверцетину і кемпоеролу, але зростає вміст глікозидів мірицетину [26]. Вони також зазначили, що фрлавонол мірицетин у найбільшій кількості міститься в зрілих плодах шовковиці білої - 0,088 \% (у перерахунку на суху речовину). Таким чином, встановлена нами присутність мірицетину в незначній кількості у випробовуваному розчині, отриманому після гідролізу сухого екстракту листя шовковиці білої, підтверджується даними авторів [26].

ВИСНОВКИ. Методом високоефективної рідинної хроматограсрії досліджено склад агліконів фрлавоноїдів сухого екстракту листя шовковиці білої. Встановлено, що вони представлені фрлавонолами: кверцетином, кемпферолом і мірицетином. Після кислотного гідролізу фрлавоноїдів сухого екстракту впродовж 2 год знайдено 0,20 \% кверцетину, 0,14 \% кемпсреролу і слідові кількості мірицетину - 0,003 \%. Отримані дані можна використати для розроблення методики стандартизації сухого екстракту листя шовковиці білої за показником "Кількісне визначення".

\section{СПИСОК ЛІТЕРАТУРИ}

1. Indian medicinal plants / K. S. Mhaskar, E. B. Latter, J. S. Caius [et al]. - Delhi : Sri Satguru Publications, 2000. - 3. - P. 3185.

2. Butt M. S., Nazir A., Sultan M.T., Schroën K. Morus alba L. nature's functional tonic // Trends in Food Science \& Technology. - 2008. - 19. - P. 505-512.

3. Metwally F. M. Morus alba L. Diminishes visceral adiposity, insulin resistance, behavioral alterations via regulation of gene expression of leptin, resistin and adiponectin in rats fed a high-cholesterol diet / F. M. Metwally, H. Rashad, A. A. Mahmoud // Physiology \& Behavior. - 2019. - 201. - P. 1-11.

4. Antioxidant flavan derivatives from the leaves of Morus alba / H-R. Zhang, M. Li, M-M. Wang [et al.] // Phytochemistry Letters. - 2019. - 29. - P. 84-90.

5. Antioxidant activities and polyphenol content of Morus alba leaf extracts collected from varying regions / Dong-Seon Kim, Young Min Kang, Wen Yi Jin [et al.] // Biomedical Reports. - 2014. - 2. - P. 675-680.

6. Grajek K. Bioactivity of Morus Alba L. extracts - an overview / K. Grajek, A. Wawro, D. Pieprzyk-Kokocha // Int. J. of Pharm. Sci. and Res. - 2015. - 6, Iss. 8. P. 3110-3122.

7. Simin Tian. Current anti-diabetes mechanisms and clinical trials using Morus alba L. / Simin Tian, Mingmin Tang, Baosheng Zhao // J. of Traditional Chinese Med. Sci. - 2016. - 3. - P. 3-8.

8. Chemical constituents of Morus alba L. and their inhibitory effect on 3T3-L1 preadipocyte proliferation and differentiation / Y. Yang, X. Yang, B. Xu [et al.] // Fitoterapia. - 2014. - 98, Iss. 10. - P. 222-227.

9. Morus Alba Linn: A Phytopharmacological review / Bandna Devi, Neha Sharma, Dinesh Kumar [et al.] // Int. J. of Pharmacy and Pharm. Sci. - 2013. - 5, Suppl. 2. P. 14-18.
10. Metabolic effects of mulberry leaves: Exploring potential benefits in type 2 diabetes and hyperuricemia / A. Hunyadi, E. Liktor-Busa, A. Marki [et al.] // EvidenceBased Complementary and Alternative Medicine. 2013. - Article ID 948627. - 10 p.

11. Zhong L. An extract of black, green, and mulberry teas causes malabsorption of carbohydrate but not of triacylglycerol in healthy volunteers / L. Zhong, J. K. Furne, M. D. Levitt // Amer. J. Clin. Nutr. - 2006. 84. - P. 551-555.

12. Цуркан О. О. Вивчення біологічно активних речовин надземної частини шовковиці білої (Morus Alba L.) і шовковиці чорної (Morus Nigra L.) / О. О. Цуркан, Т. В. Ковальчук, О. В. Гергель // Фармац. журн. 2011. - № 6. - C. 72-78.

13. Study of biologically active substances of White Mulberry leaves and their extracts / L. Vronska, A. Demyd, A. Dub [et al.] // Plant - the source of research material: $5^{\text {th }}$ International Conference and Workshop. Book of abstracts. - Lublin, 2015. - P. 167.

14. Вивчення гіпоглікемічної дії фрітозасобу, що містить сухі екстракти з листя шовковиці білої, стулок квасолі звичайної і пагонів чорниці звичайної / А. І. Дуб, І. М. Кліщ, Л. В. Вронська [та ін.] // Мед. та клініч. хімія. - 2018. - 20, № 3 (76). - С. 43-49.

15. Вивчення специфічної активності фрітозасобу, що містить сухі екстракти з листя шовковиці білої, стулок квасолі звичайної і пагонів чорниці на експериментальній моделі інсулінорезистентності, викликаної дексаметазоном / А. І. Дуб, І. М. Кліщ, Л. В. Вронська [та ін.] // Colloquium-journal. - 2018. - № 11 (22), Cz. 2. - C. 32-41.

16. Вплив концентрації етанолу в екстрагенті на фрлавоноїдний профіль витягу із листя шовковиці білої і його цукрознижувальну дію / Л. В. Вронська, А.І.Дуб, 
А. Є. Демид [та ін.] // Фармац. часоп. - 2020. - № 1. C. $5-13$.

17. Вронська Л. В. Хроматограсрічні профрілі фрлавоноїдів і гідроксикоричних кислот вітчизняних зразків лікарської рослинної сировини листя шовковиці білої / л. В. Вронська, А. Є. Демид // Фармац. часоп. - 2019. № 2. - C. 5-15.

18. Chemical characterization and antioxidative properties of Polish variety of Morus alba L. leaf aqueous extracts from the laboratory and pilot-scale processes / E. Flaczyk, J. Kobus-Cisowska, M. Przeor // Agric. Sci. 2013. - 4. - P. 141-147.

19. Free radical scavenging activity and total phenolic and flavonoid contents of mulberry (Morus spp. L., Moraceae) extracts / M. M. Radojković, Z. P. Zeković, S. S. Vidović [et al.] // Hem. Ind. -2012. -66. -P. 547-552.

20. Phytochemical profiles of different mulberry (Morus sp.) species from China / W. Song, H-J. Wang, P. Bucheli [et al.] // Agric. Food Chem. - 2009. - 57, Iss. 19. - P. 9133-9140.

21. Цуркан О. О. Фітохімічне дослідження надземної частини шовковиці білої та чорної / О. О. Цуркан, Т. В. Ковальчук, О. В. Гергель // Запорож. мед. журн. - 2012. - № 4. - С. 135-136.

\section{REFERENCES}

1. Mhaskar, K.S., Latter, E.B., Caius J.S., Kirtikar, \& Basu (2000). Indian Medicinal Plants. Delhi: Sri Satguru Publications.

2. Butt, M.S., Nazir, A., Sultan, M.T., \& Schroën, K. (2008) Morus alba L. nature's functional tonic. Trends in Food Science \& Technology, 19, 505-512. DOI:10.1016/j. tifs.2008.06.002.

3. Metwally, F.M., Rashad, H., \& Mahmoud, A.A. (2019). Morus alba L. Diminishes visceral adiposity, insulin resistance, behavioral alterations via regulation of gene expression of leptin, resistin and adiponectin in rats fed a high-cholesterol diet. Physiology \& Behavior, 201, 1-11. DOI:10.1016/j.physbeh.2018.12.010.

4. Zhang, H-R., Li, M., Wang, M-M., Wang, X-N., Shen, T., Wang, S-Q., \& Ren, D-M. (2019). Antioxidant flavan derivatives from the leaves of Morus alba. Phytochemistry Letters, 29, 84-90. DOI:10.1016/j.phytol. 2018.11.002.

5. Dong-Seon Kim, Young Min Kang, Wen Yi Jin, Yoon-Young Sung, Goya Choi, Ho Kyoung Kim. (2014). Antioxidant activities and polyphenol content of Morus alba leaf extracts collected from varying regions. Biomedical Reports, 2, 675-680. DOI: 10.3892/br.2014.294.

6. Grajek, K., Wawro, A., \& Pieprzyk-Kokocha, D. (2015). Bioactivity of Morus Alba L. extracts - an overview. Intern J. Pharm. Sci. and Res., 6 (8), 3110-3122.

7. Simin Tian, Mingmin Tang, \& Baosheng Zhao. (2016). Current anti-diabetes mechanisms and clinical trials using Morus alba L. J. of Traditional Chinese Med. Sci., 3, 3-8. DOI: 10.1016/J.JTCMS.2016.04.001.

8. Yang, Y., Yang, X., Xu, B., Zeng, G., Tan, J., He, X., ... Zhou, Y. (2014). Chemical constituents of Morus alba L. and their inhibitory effect on 3T3-L1 preadipocyte proliferation and differentiation. Fitoterapia, 98 (10), 222-227. DOI: 10.1016/j.fitote.2014.08.010
22. Державна Фармакопея України : в 3 т. / Державне підприємство "Український науковий фрармакопейний центр якості лікарських засобів". - 2-ге вид. Харків : Державне підприємство "Український науковий фармакопейний центр якості лікарських засобів". - 2014. - 3. - 732 с.

23. Вронська Л. В. ВЕРХ-дослідження агліконів фрлавоноїдів сухого екстракту пагонів чорниці / Л. В. Вронська // Фармац. часоп. - 2020. - № 3. C. $5-14$

24. Spectroscopic properties of the Chlorophyll a Chlorophyll c 2-Peridinin-Protein-Complex (acpPC) from the coral symbiotic dinoflagellate Symbiodinium / D. M. Niedzwiedzki, Jing Jiang, S. Lo Cynthia [et al.] // Photosynth. Res. - 2014. - 120, Iss. 1-2. - P. 125-139.

25. Inskeep W. P. Extinction coefficients of chlorophyll $a$ and $b$ in $N, N$-dimethylformamide and $80 \%$ acetone / W. P. Inskeep, P. R. Bloom // Plant Physiol. - 1985. 77. - P. 483-485.

26. Effect of maturity on phenolics (phenolic acids and flavonoids) profile of strawberry cultivars and mulberry species from Pakistan / Mahmood Tahir, Anwar Farooq, Abbas Mateen [et al.] // Int. J. of Mol. Sci. 2012. - 13, Iss. 12. - P. 4591-4607.

9. Bandna Devi, Neha Sharma, Dinesh Kumar, Kamal Jeet. (2013). Morus Alba Linn: A Phytopharmacological review. Int. J. Pharmacy and Pharm. Sci, 5(2), 14-18.

10. Hunyadi, A., Liktor-Busa, E., Marki, A., Martins, A., Jedlinszki, N., Hsieh T.J., ... Zupko I. (2013). Metabolic effects of Mulberry leaves: Exploring potential benefits in type 2 diabetes and hyperuricemia. EvidenceBased Complementary and Alternative Medicine, ID 948627. DOI: 10.1155/2013/948627.

11. Zhong, L., Furne, J.K., \& Levitt, M.D. (2006). An extract of black, green, and mulberry teas causes malabsorption of carbohydrate but not of triacylglycerol in healthy volunteers. Amer. J. Clin. Nutr., 84, 551-555. DOI: 10.1093/ajcn/84.3.551

12. Tsurkan, O.O., Kovachuk, T.V., \& Herhel, O.V. (2011). Vyvchennia biolohichno aktyvnykh rechovyn nadzemnoi chastyny shovkovytsi biloi (Morus Alba L.) i shovkovytsi chornoi (Morus Nigra L.) [Study of biologically active substances of the aboveground part of white mulberry (Morus Alba L.) and black mulberry (Morus Nigra L.)]. Farmats. Zhurn. - Pharm. J., 6, 72-78 [in Ukrainian].

13. Vronska, L., Demyd, A., Dub, A., Hroshoviy, T., \& Klishch, I. (2017). Study of biologically active substances of white mulberry leaves and their extracts. Abstracts of Papers. Plant - the source of research material: $5^{\text {th }}$ International Conference and Workshop. Lublin.

14. Dub, A.I., Klishch, I.M., Vronska, L.V., \& Stechyshyn, I.P. (2018). Vyvchennia hipohlikemichnoi dii fitozasobu, shcho mistyt sukhi ekstrakty z lystia shovkovytsi biloi, stulok kvasoli zvychaynoi i pahoniv chornytsi zvychaynoi [Research the hypoglycemic activity of the herbal remedy that contain dry extracts of white mulberry leaves, common bean shells and blueberry leaves]. Med. i klin. Khimiia - Medical and Clinical Che- 
mistry, (3), 44-49. DOI:10.11603/mcch.2410-681X.2018. v0.i3.9313 [in Ukrainian].

15. Dub, A.I., Klishch, I.M., Vronska, L.V., \& Stechyshyn, I.P. (2018). Vyvchennia spetsyfichnoi aktyvnosti fitozasobu, shcho mistyt sukhi ekstrakty z lystia shovkovytsi biloi, stulok kvasoli zvychaynoi i pahoniv chornytsi na eksperymentalnii modeli insulinorezystentnosti, vyklykanoi deksametazonom [Study of specific activity of phytomedicine containing dry extracts from white mulberry leaves, common bean shoots and blueberry leaves in an experimental model of insulin resistance caused by dexamethasone]. Colloquium-journal, 11 (2), 32-41 [in Ukrainian].

16. Vronska, L.V., Dub, A.I., Demyd, A.Y., Hroshovyi, T.A., \& Klishch, I.M. (2020). Vplyv kontsentratsii etanolu $v$ ekstrahenti na flavonoidnyi profil vytiahu iz lystia shovkovytsi biloi i yoho tsukroznyzhuvalnu diiu [The influence of the ethanol content in the extractant on flavonoids profile of the mulberry leaves extracts and its sugar-lowering effect]. Farm. chasopys - Pharmaceutical Review, (1), 5-13. DOI:10.11603/2312-0967.2020.1.10983 [in Ukrainian].

17. Vronska, L.V., \& Demyd, A.Y. (2019). Khromatohrafichni profili flavonoyidiv i hidroksykorychnykh kyslot vitchyznianykh zrazkiv likarskoi roslynnoi syrovyny lystia shovkovytsi biloi [Flavonoids and hydroxycinnamic acids chromatographic profiles of domestic raw materials of mulberry white leaves]. Farm. chasopys - Pharmaceutical Review, 2, 5-15. DOI: 10.11603/2312-0967.2019. 2.10269 [in Ukrainian].

18. Flaczyk, E., Kobus-Cisowska, J., Przeor M., Korczak, J., Remiszewski, M., Korbas E., \& Buchowski, M. (2013). Chemical characterization and antioxidative properties of Polish variety of Morus alba L. leaf aqueous extracts from the laboratory and pilot-scale processes. Agric. Sci., 4, 141-147. DOI: 10.4236/as.2013.45B026

19. Radojković, M.M., Zeković, Z.P., Vidović, S.S., Kočar, D.D., \& Mašković, P.Z. (2012). Free radical scavenging activity and total phenolic and flavonoid contents of mulberry (Morus spp. L., Moraceae) extracts. Hem. Ind., 66, 547-552. DOI: 10.2298/HEMIND111111002R.
20. Song, W., Wang, H.-J., Bucheli, P., Zhang, P.-F., Wei, D.-Z., \& Lu, Y.-H. (2009). Phytochemical profiles of different mulberry (Morus sp.) species from China. J. Agric Food Chem., 57 (19), 9133-9140. DOI: 10.1021/ jf9022228.

21. Tsurkan, O.O., Kovalchuk, T.V., \& Herhel, O.V. (2012). Fitokhimichne doslidzhennia nadzemnoi chastyny shovkovytsi biloi ta chornoi [Phytochemical study of the aboveground part of white and black mulberry]. Zapor. med. zhurn. - Zaporozhye Medical Journal, 4, 135-136 [in Ukrainian].

22. (2014). Derzhavna Farmakopeia Ukrainy: v 3 t./DP «Ukrainskyi naukovyi farmakopeinyi tsentr yakosti likarskykh zasobiv. - 2-e vyd. [The State Pharmacopoeia of Ukraine: in 3 vol. Kharkiv: Ukrainian Scientific Pharmacopoeia Center of Quality of Medicinal Products. Ed. 2. Vol. 3.]. Kharkiv: Ukrainian Scientific Pharmacopoeia Center of Quality of Medicinal Products. [in Ukrainian]

23. Vronska, L.V. (2020). VERKH-doslidzhennia ahlikoniv flavonoidiv sukhoho ekstraktu pahoniv chornytsi [HPLC-research of the flavonoid aglycones of bilberry shoots dry extract]. Farm. chasopys - Pharmaceutical Review, (3), 5-14. DOI: 10.11603/2312-0967.2020. 3.11424 [in Ukrainian]

24. Niedzwiedzki, D.M., Jiang, J., Lo, C.S., \& Blankenshi, R.E. (2014). Spectroscopic properties of the Chlorophyll a - Chlorophyll c 2-Peridinin-Protein-Complex (acpPC) from the coral symbiotic dinoflagellate Symbiodinium. Photosynth. Res., 120 (1-2), 125139. DOI:10.1007/s11120-013-9794-5.

25. Inskeep, W.P., \& Bloom, P.R. (1985). Extinction coefficients of chlorophyll $a$ and $b$ in $N, N$-dimethylformamide and $80 \%$ acetone. Plant Physiol., 77, 483-485. DOI: $10.1104 / p p .77 .2 .483$.

26. Mahmood Tahir, Anwar Farooq, Abbas Mateen, \& Saari Nazamid (2012). Effect of maturity on phenolics (phenolic acids and flavonoids) profile of strawberry cultivars and mulberry species from Pakistan. Int. J. Mol. Sci., 13 (12), 4591-4607. DOI:10.3390/ijms13044591.

Л. В. Вронска

ТЕРНОПОЛЬСКИЙ НАЦИОНАЛЬНЫЙ МЕДИЦИНСКИЙ УНИВЕРСИТЕТ ИМЕНИ И. Я. ГОРБАЧЕВСКОГО МОЗ УКРАИНЫ

\section{ИЗУЧЕНИЕ АГЛИКОНОВ ФЛАВОНОИДОВ СУХОГО ЭКСТРАКТА ЛИСТЬЕВ ШЕЛКОВИЦЫ БЕЛОЙ МЕТОДОМ ВИСОКОЭФФЕКТИВНОЙ ЖИДКОСТНОЙ ХРОМАТОГРАФИИ}

\section{Резюме}

Вступление. Флавоноиды шелковицы белой представлены различными гликозидами, что затрудняет стандартизацию по их содержанию как сырья, так и ее экстрактов. Учитывая разнообразие гликозидных форм фрлавоноидов, присутствие других веществ френольной природы, которые по аналитико-фрункциональным свойствам являются родственными с фрлавоноидами, спектрофотометрическое определение последних очень затруднено.

Цель исследования - изучить состав и содержание агликонов фрлавоноидов в сухом экстракте листьев шелковицы белой.

Методы исследования. Сухой экстракт листьев шелковицы белой получали из сырья отечественного происхождения методом дробной мацерации; экстрагент - этанол (80-60 \% об/об); экстракционное соотношение сырье:экстрагент - 1:9-15, кратность экстрагирования - 5, время одного экстрагирова- 
ния - 24 ч. В исследовании применяли: роторный испаритель Laborota 4011 (Heidolph Instruments GmbH \& Сo. KG, Германия), сушильный шкафр CП-100 (UOSLAB, Украuна), аналитические весы Mettler Toledo XP205DR (Mettler Toledo, Швейцария), ультразвуковую баню Bandelin Sanorex digitec (BANDELIN electronic GmbH \& Co. KG, Германия), жидкостной хроматографр Agilent 1200 с детектором G1315D DAD (“Agilent”, СШA), хроматографрическую колонку Kromasil 100 C18 (0,125 м × 4,6 мм, 5 мкм, Supelko, США), стандарты агликонов (Sigma-Aldrich), химические реактивы аналитической чистоты и растворители для градиентного элюирования (Sigma-Aldrich, Macron Fine Chemicals тм).

Результаты и обсуждение. Агликоны фрлавоноидов получали путем кислотного гидролиза навески сухого экстракта в течение 2 ч. Полученные агликоны извлекали путем исчерпывающей экстракции этилацетатом; отгоняли растворитель, а сухой остаток, содержащий исследуемые агликоны, растворяли в метаноле, готовя испытуемые растворы для ВЭЖХ-изучения. На хроматограммах испытуемых растворов наблюдали появление ряда пиков, три из которых соответствовали мирицетину, кверцетину и кемпферолу. Таким образом, фрлавоноиды сухого экстракта листьев шелковицы белой представлены гликозидами указанных трех фрлавонолов. Данные о наличии кверцетина и кемпферола совпадают с данными исследований других авторов.

Выводы. Исследован состав агликонов фрлавоноидов сухого экстракта листьев шелковицы белой. Установлено, что они представлены фрлавонолами: кверцетином, кемпферолом и мирицетином. Найдено 0,20 \% кверцетина, 0,14 \% кемпферола и следовые количества мирицетина - 0,003 \%. Полученные данные можно использовать для разработки методики стандартизации сухого экстракта листьев шелковицы белой по показателю "Количественное определение".

КЛЮЧЕВЫЕ СЛОВА: листья шелковицы белой; сухой экстракт; агликоны; кверцетин; кемпферол; мирицетин.

\author{
L. V. Vronska
}

I. HORBACHEVSKY TERNOPIL NATIONAL MEDICAL UNIVERSITY

\title{
STUDY OF FLAVONOID AGLICONES OF THE MULBERRY WHITE LEAVES DRY EXTRACT BY THE HPLC METHOD
}

\section{Summary}

Introduction. The flavonoids of the white mulberry leaves are represented by various glycosides, which complicate the standardization of their content of both - raw materials and its extracts. The spectrophotometric determination of flavonoids is difficult due to the variety of glycosides forms of flavonoids, and the presence of other phenolic nature substances, which have the similar to flavonoids analytical properties.

The aim of the study - to research the composition and content of flavonoid aglycones in the white mulberry leaves dry extract.

Research Methods. Dry extract of the white mulberry leaves was obtained from raw materials of domestic origin by fractional maceration; extractant - ethanol (80-60\%, v/v); extraction ratio - 1: 9-15, the multiplicity of extraction - 5, the currency of the one extraction - $24 \mathrm{~h}$. Laborota 4011 rotary evaporator (Heidolph Instruments GmbH \& Co. KG, Germany), SP-100 drying cabinet (UOSLAB, Ukraine), Mettler Toledo XP205DR analytical scale (Mettler Toledo, Switzerland), Bandelin Sanorex digitec electronic ultrasonic bath (GmbH \& Co. KG, Germany), Agilent 1200 liquid chromatograph with G1315D DAD Detector (Agilent, USA), Kromasil 100 C18 $(0.125 \mathrm{~m} \times 4.6 \mathrm{~mm}$, $5 \mu \mathrm{m}$, Supelko, USA) chromatographic column, aglycones standards (Sigma-Aldrich), chemical reagents of analytical grade and solvents of HPLC-grade (Sigma-Aldrich, Macron Fine Chemicals ${ }^{\mathrm{TM}}$ ) were used in the study.

Results and Discussion. The flavonoid aglycones were obtained by the acid hydrolysis of the dry extract sample carried out during 2 hours. Separation of the obtained aglycones was performed by exhaustive extraction with ethyl acetate. For HPLC, the solvent was distilled off, and the dry residue containing the test aglycones was dissolved in methanol to prepare the test solutions. A number of peaks were observed on the chromatograms of the test solutions, three of which corresponded to myricetin, quercetin and kaempferol. Therefore, the flavonoids of the dry extract of white mulberry leaves are represented by glycosides of these three flavonols. Data on the presence of quercetin and kaempferol coincide with data from studies by other authors.

Conclusions. The composition of flavonoid aglycones of the white mulberry leaves dry extract was studied. It was found that they are represented by flavonols: quercetin, kaempferol and myricetin. $0.20 \%$ of quercetin, $0.14 \%$ of kaempferol and trace amounts of myricetin - $0.003 \%$ were found. The obtained data can be used to develop a method of standardization of white mulberry leaves dry extract on the indicator "Quantitative determination".

KEY WORDS: white mulberry leaves; dry extract; aglycones; quercetin; kaempferol; myricetin.

Адреса для листування: Л. В. Вронська, Тернопільський національний медичний університет імені І. Я. Горбачевського МОз України, Тернопіль, 46001, Україна, e-mail: vronska_liudmyla@ukr.net. 